\title{
Possible evolution of mobile animals in association with microbial mats
}

\author{
Murray Gingras ${ }^{1 \star}$, James W. Hagadorn ${ }^{2}$, Adolf Seilacher ${ }^{3}$, Stefan V. Lalonde ${ }^{4}$, Ernesto Pecoits ${ }^{1}$, \\ Daniel Petrash ${ }^{1}$ and Kurt O. Konhauser ${ }^{1}$
}

\begin{abstract}
Complex animals first evolved during the Ediacaran period, between 635 and 542 million years ago, when the oceans were just becoming fully oxygenated. In situ fossils of the mobile forms of these animals are associated with microbial sedimentary structures ${ }^{1-3}$, and the animal's trace fossils generally were formed parallel to the surface of the seabed, at or below the sediment-water interface $e^{4,5}$. This evidence suggests the earliest mobile animals inhabited settings with high microbial populations, and may have mined microbially bound sediments for food resources ${ }^{6-8}$. Here we report the association of mobile animals-insect larvae, oligochaetes and burrowing shore crabs-with microbial mats in a modern hypersaline lagoon in Venezuela. The lagoon is characterized by low concentrations of dissolved $\mathrm{O}_{2}$ and pervasive biomats dominated by oxygen-producing cyanobacteria, both analogous to conditions during the Ediacaran. We find that, during the day, $\mathrm{O}_{2}$ levels in the biomats are four times higher than in the overlying water column. We therefore conclude that the animals harvest both food and $\mathrm{O}_{2}$ from the biomats. In doing so, the animals produce horizontal burrows similar to those found in Ediacaran-aged rocks. We suggest that early mobile animals may have evolved in similar environments during the Ediacaran, effectively exploiting oases rich in $\mathrm{O}_{2}$ that formed within low oxygen settings.
\end{abstract}

Although it is hypothesized that the appearance of the earliest mobile animals (putatively bilaterians) was made possible by the increasing abundance of dissolved oxygen in oceanic waters, dissolved oxygen $\sim 600 \mathrm{Myr}$ was probably spatially variable and low overall, ranging between 10 and $18 \%$ of today's levels ${ }^{9,10}$. To most modern animals, persistently low oxygen concentrations are lethal-suggesting either that the first bilaterians were metabolically different from their modern counterparts, or that they exploited heretofore unrecognized sources of oxygen in the Ediacaran seas. Is it possible that oases of high oxygen concentration were present well before the Ediacaran and that they persisted in Ediacaran shallow marine environments, where photosynthetic biomats produced copious amounts of oxygen that diffused into the adjacent sediment and water column? Modern biomats-discussed belowcommonly have daytime oxygen concentrations that exceed atmospheric levels by several orders of magnitude ${ }^{11}$. This leads us to hypothesize that the first bilaterian animals did not need to evolve the ability to withstand low oxygen concentrations so much as to cope with spatiotemporal variability in oxygen availability.

The trace-fossil record of bilaterian metazoans extends to the late Ediacaran about 555 Myr ago $^{12}$ (perhaps as early as 565 Myr; ref. 13) and these fossils show a wide range of interactions with fossilized biomats. Many of these interactions record animal grazing on biomats as a food resource. Examples of this include radular rasping at the top of fossil mats ${ }^{6,14-16}$ or systematic probing and mining at the base of fossil biomats ${ }^{17,18}$. By the dawn of the Cambrian period, back-filled undermat grazing burrows are comparably common. Although Ediacaran and Cambrian biomats have been hypothesized to be an important food resource for early animals, and despite the important role biomats played with respect to local $\mathrm{O}_{2}$ distribution ${ }^{17,19,20}$, the mats have not been recognized as a local source of oxygen in otherwise microaerophilic settings. It is logical that animals living under, or within, photosynthetic biomats should equally have been capable of exploiting the locally rich oxygen resources present.

Modern biotic settings with living conditions analogous to Ediacaran sea floors include hypersaline lagoons of the Los Roques Archipelago, Venezuela. In the Los Roques lagoons, high salinity impedes biomat degradation by grazing invertebrates. Thus, well-developed biomats-along with gypsum and carbonate-cemented crusts-are observed locally. The lagoons of the archipelago are tropical $\left(11^{\circ} 51.5^{\prime} \mathrm{N} 66^{\circ} 45.5^{\prime} \mathrm{W}\right.$; Supplementary Fig. S1) and have high salinities (70-90 ppt in February 2009) and warm water temperatures (up to $40^{\circ} \mathrm{C}$ ), which result in a decreased dissolved oxygen concentration. Layered biomats, with an uppermost population of cyanobacteria overlying a mixed chemolithoautotrophic-phototrophic community of sulphide-oxidizing bacteria, are typically present in the shallow, subtidal parts of the lagoons (Supplementary Fig. S2 shows examples of the biomat). At both locales, the daytime bottom waters had $\mathrm{O}_{2}$ partial pressures near to or above those dictated by atmospheric equilibrium (partial pressure $0.25-0.45 \mathrm{~atm}$ ) and contained no $\mathrm{H}_{2} \mathrm{~S}$ (Fig. 1). At $1 \mathrm{~mm}$ below the biomat-water interface, the partial pressure of oxygen rose dramatically to levels indicating a nearly pure $\mathrm{O}_{2}$ gas environment (partial pressure 0.95-1.05 atm). Between 4 and $10 \mathrm{~mm}$ depth, the sediment abruptly became anoxic, and then sulphidic. The fluctuating gas concentrations correspond to: (1) normal to elevated water column $\mathrm{O}_{2}$ concentrations determined by atmospheric equilibrium, with inheritance from the $\mathrm{O}_{2}$-producing mats below; (2) highest $\mathrm{O}_{2}$ concentrations occurring within the upper cyanobacterial layers of the biomats; (3) falling and very low $\mathrm{O}_{2}$ in the sulphide-oxidizing layers of the biomat; and (4) elevated $\mathrm{H}_{2} \mathrm{~S}$ in the sulphate-reducing zone of the biomat's underlying sediment. Night-time measurements indicate that the sediment becomes sulphidic up to the biomat-water interface and that $\mathrm{O}_{2}$ levels are reduced in the water adjacent to the biomat (Supplementary Fig. S3).

\footnotetext{
${ }^{1}$ Department of Earth and Atmospheric Science, 1-26 Earth Science Building, University of Alberta, Edmonton, Alberta, T6G 2E3, Canada, ${ }^{2}$ Department of Earth Sciences, Denver Museum of Nature and Science, Denver, Colorado 80205, USA, ${ }^{3}$ Department of Geology and Geophysics, Yale University, New Haven, Connecticut 06520, USA, ${ }^{4}$ Laboratoire Domaines Océaniques, Institut Universitaire Européen de la Mer, Université de Bretagne Occidentale, Place Nicholas Copernic, Technopôle Brest-Iroise, 29280 Plouzané, France. *e-mail:mgingras@ualberta.ca.
} 
a

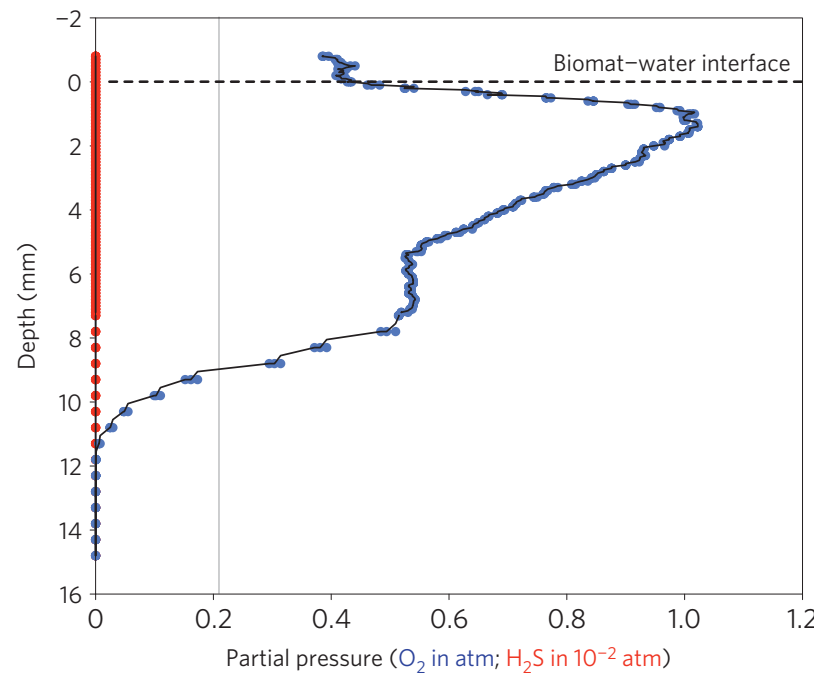

b

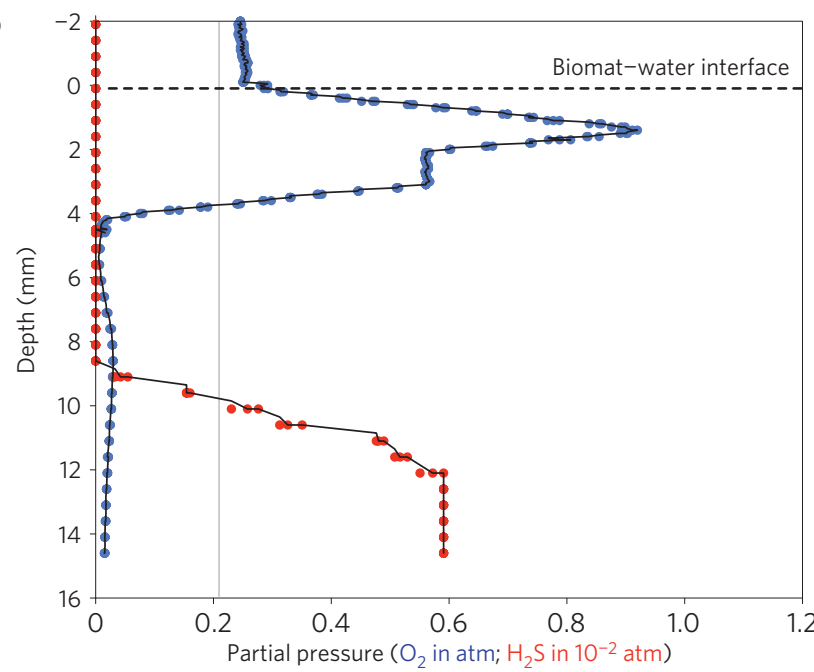

Figure 1 | Clark-type microelectrodes ( $50 \mu \mathrm{M}$ tip diameter) were used to measure the in situ $\mathrm{O}_{2}$ and $\mathrm{H}_{2} \mathrm{~S}$ partial pressures in the bottom water, biomat and underlying sediment. Shown here are daytime profiles of dissolved $\mathrm{O}_{2}$ and $\mathrm{H}_{2} \mathrm{~S}$ in the water above, and in the biolaminated sediments, at $\mathbf{a}$, Augustana Lagoon and $\mathbf{b}$, Pirata Lagoon. In both examples, $\mathrm{O}_{2}$ concentrations within the biomat $(0$ to $-4 \mathrm{~mm})$ are substantially higher than the $\mathrm{O}_{2}$ concentrations in the overlaying water. In a, the $\mathrm{H}_{2} \mathrm{~S}$-producing zone is deeper than the probe's terminal position. Night-time measurements are shown in Supplementary Fig. S3.

Lagoonal waters are populated only by free-swimming water-striders (heteropterids). Beneath the biomats, at the interface between the cyanobacteria and the sulphide-oxidizers, live several other animals (Supplementary Fig. S4), including the larvae of the dipteran insects Ephydridae, Stratiomyidae and Tabanidae; coleopteran larvae of Hydrophilidae; and a small, unidentified oligochaete. The sub-mat population maintains no irrigation burrows to the sediment-water interface and thrives independently of the lagoonal waters. The complete absence of perforations and burrows through the biomat confirm that the animals hibernate beneath the mat throughout the high-sulphide evening cycle, a behaviour documented in hypoxia-tolerant insect larvae ${ }^{21}$. Also locally present is the shore crab Pachygrapsus crassipes, which lives below the biomat, but maintains open burrows to the lagoon waters. In contrast, non-mat containing sediments are typically impoverished of (macroscopic) infauna (Supplementary Fig. S5).
The exploitation of modern biomats and sub-mat oxygen by burrowing animals demonstrates the viability of undermat lifestyles, which result from the presence of readily accessible food and oxygen. These factors logically conspire to afford an infaunal sub-mat biome, but this is an underappreciated mechanism to explain a means by which metazoans persist in, and perhaps evolved into, low-oxygen settings.

No modern environment can be considered to be a strict analogue to shallow Ediacaran oceans. However, the Los Roques lagoons and their invertebrate infauna have in common some important characteristics. Chemically speaking, the warm lagoonal waters have reduced oxygen concentrations compared with bulk sea water. Owing to elevated salinities in the modern locales, biomat growth exceeds animal grazing, thus biomats provide the commonest substratum and the sediment is dominantly stabilized and immobile. The arthropod larvae and oligochaetes employ simple burrowing strategies (for example, unlined shafts and tunnels) that are likewise observed in late Ediacaran and younger rocks. Also, the simple functional morphologies of the observed animals (that is poorly developed appendages, somewhat vermiform: Supplementary Fig. S4a-e) are analogous to the bauplans of early metazoans.

We assert that in the Ediacaran the pervasive distribution of biomats and somewhat lower concentrations of dissolved $\mathrm{O}_{2}$ in marine settings similarly obliged animals to locally exploit oxygen oases associated with cyanobacterial biomats. The employment of burrowing behaviours was probably not limited to biomat exploitation, but provided a means of accessing the rich biomat food resource whilst using the higher sub-mat $\mathrm{O}_{2}$ concentrations. This suggests that, like the infaunal inhabitants of the Los Roques lagoons, early motile bilaterians had to: (1) contend with potentially patchy oxygen resources ${ }^{22}$; (2) broadcast larvae in a variably oxygenated landscape; and, (3) withstand regular exposure to the anoxia and elevated sulphide concentrations that accompany nightly cessation of oxygen production. Living under such conditions would require that the earliest bilaterians live short and opportunistic lifestyles. Rapid reproduction and growth (that is, $\mathrm{r}$-selection) would be requisite in a variably oxygenated setting (see Supplementary Discussion Section S1).

In the rock record, some trace fossil occurrences are, in fact, best explained by exploitation of biomats for their oxygen production as opposed to their food value. In that context, we reinterpret below some characteristic Ediacaran and Lower Palaeozoic trace-fossils, which are commonly observed in association with biolaminated sediment. Hypothesized oxygen-exploitive trace fossils have some of the following characteristics (Figs 2 and 3): (1) the burrow was connected to the sediment-water interface and was maintained as an open living chamber, but shows optimization of burrow surface area or volume beneath biomat zones (for example, Chondrites Fig. 3a); (2) the burrow is situated at the base of biomats and has no connection to the sediment-water interface (Fig. 3c); or, (3) the trace fossil is preserved immediately beneath fossil biomats and may have been back-filled during trace-fossil emplacement (Fig. 3c,d) (see Supplementary Discussion Section S2).

Some styles of oxygen mining may exhibit more than one of the characteristics suggested above. For example, the trace fossil Eochondrites rectangularis (n. igen., n. isp.) (Fig. 3b; Supplementary Taxonomic Appendix) shows extreme maximization of belowmat surface-area, shows no aperture to the sediment-water interface, and displays regularly meniscate back-filling of cavernous spaces isolating itself from irrigation tunnels (Supplementary Fig. S6). The meniscate-filled tunnels, which are associated only with biogenic sedimentary structures, cannot be explained by sedimentary or hydraulic processes. The enlarged, clavate tunnels attest to the cohesive nature of the overlaying mat and the sub-mat sediment, both of which enabled the trace maker to 

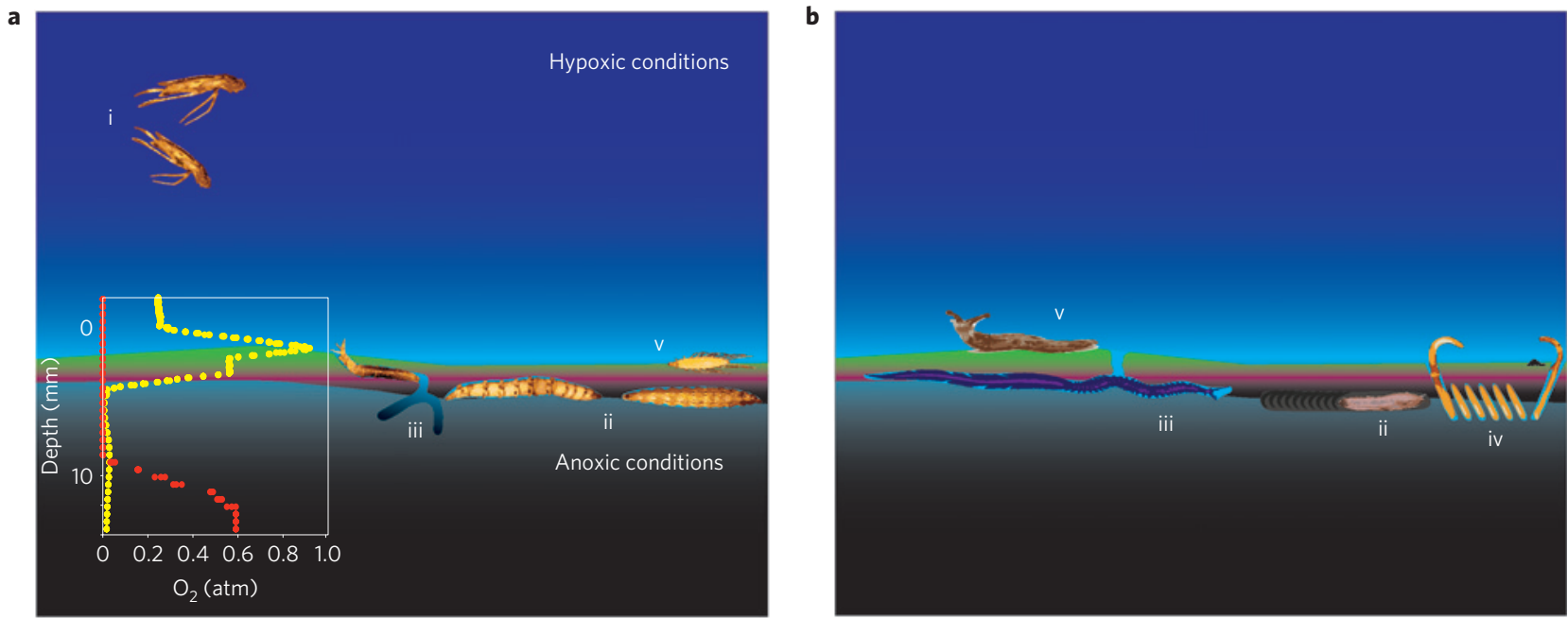

Figure 2 | Schematic showing behaviours associated with oxygen oases. a, Modern animal-biomat associations from Los Roques. b, Potential Upper Ediacaran and Lower Cambrian associations. Various lifestyles are illustrated: (i) free swimming animals that dive into zones of higher oxygen content (ii) animals that reside in burrows isolated from the water column; (iii) open, branching networks provide access to the sediment-water interface and permit sub-mat feeding and exploitation of $\mathrm{O}_{2}$ above and below the biomat; (iv) burrows that maximize their surface area below biomats stand to increase $\mathrm{O}_{2}$ flux through the burrow wall; and (v) bottom-hugging animals residing within the oxycline.

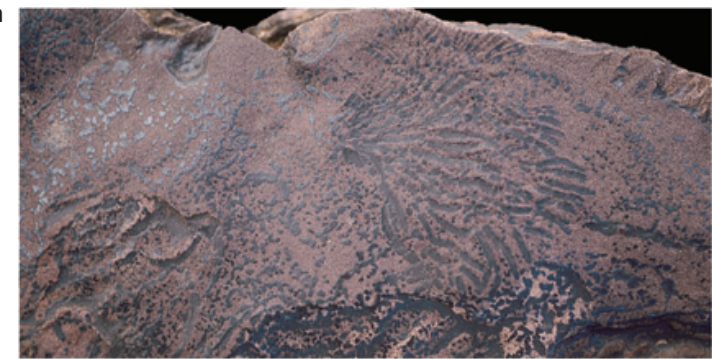

b

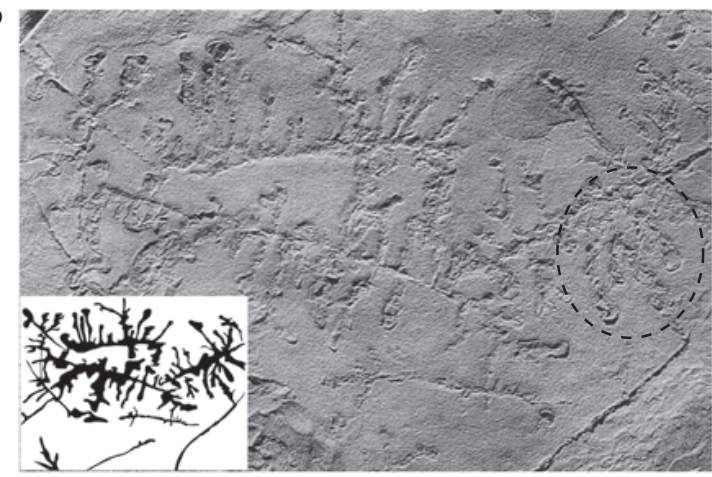

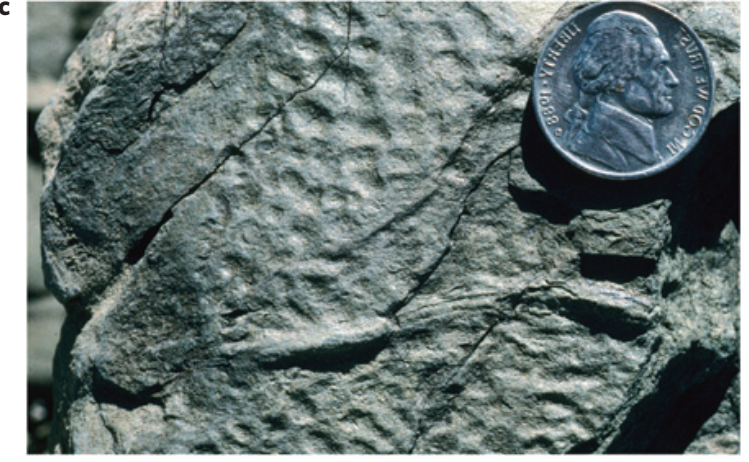

d

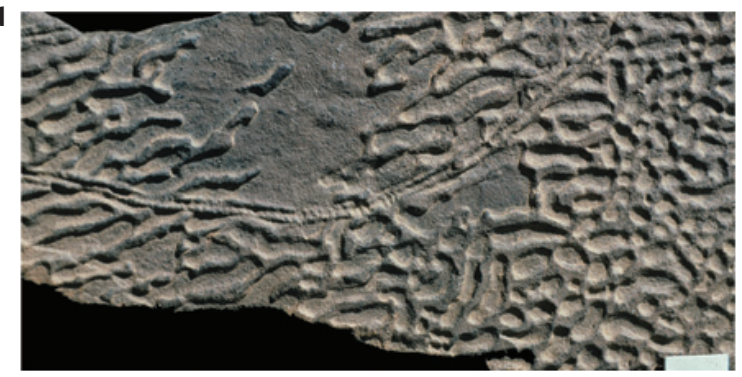

Figure 3 | Examples of undermat trace fossils. a, Oldhamia-like trace fossil preserved beneath biomat lamination; Ediacaran Rawnsley Quartzite,

S. Australia (11 cm wide). b, Eochondrites showing substantial below-mat exploitation. Back-fill structures are visible (indicated by ellipse). Upper Cambrian of Huquf, Oman ( $28 \mathrm{~cm}$ wide). c, Back-filled tunnel mantled by biomat wrinkle structures; Early Cambrian Harkless Formation, California. As a result of back-filling during construction, animals associated with such traces would have drawn $\mathrm{O}_{2}$ from the biomat. d, Back-filled trace fossil associated with Kinneyia structures, which only form beneath biomats ${ }^{25,26}$; Silurian Acacus Sandstone, Libya (cm scale lower right). a: bed sole; b-d: bed tops.

leave a literal mine-working in its wake (see Supplementary Discussion Section S3).

The distribution of mat-associated $\mathrm{O}_{2}$ exploitation would be limited to cyanobacterial biomats. Sulphide-oxidizing mats, for example Thioploca sp., may have been exploited as a food resource, but oxygen would have been required to form the nitrate, which they use as their electron acceptor ${ }^{23}$, and the grazing animals would have been dependent on oxygen from the bottom ocean water itself. It is likely that sessile organisms, such as Dickinsonia, Parvancorina, Spriggina, and Tribrachidium-characteristic
Ediacaran fauna-were better able to persist in such (deeper water) conditions. An important consideration, then, is that the landscape of early animal evolution was in part shaped by the distribution of biomats and that the animal invasion could have been directed from at least two fronts. We emphasize that oxygen mining behaviours do not necessarily represent the leading edge of animal evolution, but that they probably represent the motivation for and onset of animal motility.

The recognition of sub-mat oxygen mining potentially addresses an evolutionary conundrum: if bilaterians evolved-as indicated 
by molecular clocks-before or near to $600 \mathrm{Myr}$ ago (ref. 24), how did the emergent animals manage to cope with dissolved oxygen concentrations within (Ediacaran) oceanic waters that were likely to be extremely spatiotemporally variable and as low as $10 \%$ of modern levels ${ }^{10}$ ? Or did metazoans first exploit highly oxygenated biomat oases and progressively radiate into settings characterized by lower (oceanic) oxygen concentrations? The common occurrence of Ediacaran and Lower Cambrian biomat-associated trace fossils certainly supports the contention that early metazoans exploited sub-biomat oxygen sources whilst foraging for food. Logically, $\mathrm{O}_{2}$ concentrations were higher near oxygenic biomats. Our evaluation of the Los Roques assemblage and some Ediacaran trace fossils supports the premise that, in accordance with prevailing $\mathrm{O}_{2}$ distributions, the earliest motile metazoans may well have favoured bottom-hugging ethologies, which were coupled to the ability to withstand temporary sulphidic conditions through lowered metabolic states. These behaviours were ultimately modified for substratal and sub-mat lifestyles; the latter became very important in the Lower Palaeozoic, and in the guise of hypoxia-tolerant physiologies (for example, capitellid polychaetes) are still common today. As oceans became progressively oxygenated, the dependence on mat-associated $\mathrm{O}_{2}$ was eliminated and the associated ethologies became subordinate. The recognition that metazoans engage in the mining of oxygen produced by photosynthetic mats is not only crucial for interpreting bioturbation observed in Neoproterozoic and lower Palaeozoic strata, but more importantly, it provides a 'missing link' in terms of the environmental settings that fostered the early evolution of $\mathrm{O}_{2}$-dependent animals in waters that had yet to become fully oxygenated.

\section{Received 3 January 2011; accepted 13 April 2011; published online 15 May 2011}

\section{References}

1. Droser, M. L., Gehling, J. G. \& Jensen, S. R. Assemblage palaeoecology of the Ediacara biota: The unabridged edition? Palaeogeogr. Palaeoclimatol. Palaeoecol. 232, 131-147 (2006).

2. Fedonkin, M. A., Simonetta, A. \& Ivantsov, A. Y. in The Rise and Fall of the Ediacaran Biota 157-179 (Special Publications Vol. 286, Geological Society, 2007).

3. Gehling, J. G. \& Droser, M. L. Textured organic surfaces associated with the Ediacara biota in South Australia. Earth Sci. Rev. 96, 196-206 (2009).

4. Jensen, S., Droser, M. L. \& Gehling, J. G. Trace fossil preservation and the early evolution of animals. Palaeogeogr. Palaeoclimatol. Palaeoecol. 220, 19-29 (2005).

5. Jensen, S., Droser, M. L. \& Gehling, J. G. A critical look at the Ediacaran trace fossil record. Top. Geobiol. 27, 115-157 (2006).

6. Seilacher, A. \& Pflüger, F. in Biostabilization of Sediments (eds Krumbein, W., Paterson, D. M. \& Stal, L. J.) 97-105 (Bibliotheks und Informationssystem der Universität Oldenburg, 1994).

7. Gehling, J. G. Microbial mats in terminal Proterozoic siliciclastics; Ediacaran death masks. Palaios 14, 40-57 (1999).

8. Seilacher, A., Buatois, L. A. \& Mangano, M. G. Trace fossils in the Ediacaran-Cambrian transition: Behavioural diversification, ecological turnover and environmental shift. Palaeogeogr. Palaeoclimatol. Palaeoecol. 227, 323-356 (2005).
9. Canfield, D. E. \& Teske, A. Late Proterozoic rise in atmospheric oxygen concentration inferred from phylogenetic and sulphur-isotope studies. Nature 382, 127-132 (1996).

10. Canfield, D. E., Poulton, S. W. \& Narbonne, G. M. Late-Neoproterozoic deep-ocean oxygenation and the rise of animal life. Science 315, 92-95 (2007).

11. Canfield, D. E. \& Des Marais, D. J. Biogeochemical cycles of carbon, sulfur, and free oxygen in a microbial mat. Geochim. Cosmochim. Acta 57, 3971-3984 (1993).

12. Martin, M. W. et al. Age of Neoproterozoic bilatarian body and trace fossils, White Sea, Russia: implications for metazoan evolution. Science 288, 841-845 (2000).

13. Liu, A. G., Mcllroy, D. \& Brasier, M. D. First evidence for locomotion in the Ediacara biota from the 565 ma Mistaken Point Formation, Newfoundland. Geology 38, 123-126 (2010).

14. Gehling, J. G. Taphonomy of the Terminal Proterozoic Ediacara Biota, South Australia. Doctoral, Univ. of California at Los Angeles, Univ. Microfilms (1996).

15. Fedonkin, M. A. \& Setoguchi, T. The origin of the Metazoa in the light of the Proterozoic fossil record. Paleontol. Res. 7, 9-41 (2003).

16. Seilacher, A. \& Hagadorn, J. W. Early molluscan evolution: evidence from the trace fossil record. Palaios 25, 565-575 (2010).

17. Seilacher, A. Biomat-related lifestyles in the Precambrian. Palaios 14, 86-93 (1999).

18. Jensen, S., Saylor, B. Z., Gehling, J. G. \& Germs, G. J. B. Complex trace fossils from the terminal Proterozoic of Namibia. Geology 28, 143-146 (2000).

19. Brasier, M. D. Background to the Cambrian explosion. J. Geol. Soc. 149, 585-587 (1992).

20. McIlroy, D. \& Logan, G. A. The impact of bioturbation on infaunal ecology and evolution during the Proterozoic-Cambrian transition. Palaios 14, 58-72 (1999)

21. Nagell, B. \& Landahl, C. C. Resistance to anoxia of Chironomus plumosus and Chironomus anthracinus (Diptera) larvae. Ecography 1, 333-336 (1978).

22. Plotnick, R. E. Chemoreception, odor landscapes, and foraging in ancient marine landscapes. Palaeontol. Electron. 10, 11 (2007).

23. Fossing, H. et al. Concentration and transport of nitrate by the mat-forming sulphur bacterium Thioploca. Nature 374, 713-715 (2002).

24. Peterson, K. J., Cotton, J. A., Gehling, J. G. \& Pisani, D. The Ediacaran emergence of bilaterians: congruence between the genetic and the geological fossil records. Phil. Trans. R. Soc. B 363, 1435-1443 (2008).

25. Pflüger, F. Matground structures and redox facies. Palaios 14, 25-39 (1999).

26. Porada, H., Ghergut, J. \& Bouougri, E. H. Kinneyia-type wrinkle structures — critical review and model of formation. Palaios 23, 65-77 (2008).

\section{Acknowledgements}

S. G. Pemberton, N. Butterfield and S. Jensen are thanked for their technical input and evaluation. M.G. and K.O.K. thank the Natural Sciences and Engineering Research Council of Canada for ongoing support.

\section{Author contributions}

M.G. and K.O.K. conceived the study and led field operations: S.V.L., E.P. and D.P. executed different aspects of the data gathering and data analysis: J.W.H. and A.S. provided ancient rock-record examples. All of the authors contributed to the writing of the final manuscript.

\section{Additional information}

The authors declare no competing financial interests. Supplementary information accompanies this paper on www.nature.com/naturegeoscience. Reprints and permissions information is available online at http://www.nature.com/reprints. Correspondence and requests for materials should be addressed to M.G. 